\title{
THE IMPACT OF INTERNATIONAL LABOUR MIGRATION ON THE DEVELOPMENT OF STATES UNDER GLOBALIZATION: ECONOMIC AND LEGAL ASPECTS
}

\author{
Nadiya Bortnyk' \\ Institute of Law and Psychology, Lviv Polytechnic National University, Ukraine
}

Galyna Didkivska², Vyacheslav Tylchyk ${ }^{3}$

National University of the State Fiscal Service of Ukraine, Ukraine

\begin{abstract}
The purpose of this article is to conduct an economic and legal analysis of the current situation of international labour migration and its impact on the development of states in a globalized world. It is stressed that modern globalization has not slowed migration flows but, on the contrary, significantly increased them and created the so-called "era of migration". The article reveals the meaning and significance of international labour migration, acquired at the beginning of the XXI century. The key definitions of the research and the theory of the emergence of migration are presented. The role of labour migration in redressing imbalances, which exist in the labour market, is analysed. The genesis of the migration policy of the world leading countries regarding the admission of labour migrants to their territories is considered. The mechanism of legal regulation of some donor countries and recipient countries is revealed. The causes of external labour migration and its consequences for Ukraine are considered. The prospects for improvement in the migration policy of Ukraine in the context of globalization and European integration processes are outlined. An attention is paid to the importance of international labour migration for the economic development of the state, which receives migrants and one from which they originate. Primary theoretical and practical significance of international labour migration for the industrialized countries of the world, which due to acute demographic challenges cannot provide development and normal functioning of the economy without the involvement of labour migrants, is highlighted. The article aims to consider international labour migration as an integral part of the global economy and to identify peculiarities of international labour migration, as well as its place in international economic relations. At the same time, an attention is paid to the fact that labour migration abroad is the most powerful migration process in Ukraine today, which increases the importance of studying the issues of state policy development in the area of regulation and strengthening the protection of the rights of Ukrainian citizens who travel abroad as migrant workers. Besides, it is focused on the issue of the creation of a global market of skilled labour, as well as the consequences of migration of skilled personnel and the challenge of overcoming the negative consequences of the migration of skilled workers. It is noted that the world (global) labour market is a set of global labour resources as the sum of all occupied (real and potential) population of the world, including international labour migrants. Given this, temporally dynamic changes, taking place in the area of displacement of international labour migrants, particularly in Ukraine, as well as in the migration mood of the Ukrainian population, require their constant monitoring and scientific substantiation. The practical importance of the scientific research is to clarify the causes and consequences of international labour migration for the development of the receiving states and those that generate them. This is extremely important for the improvement of the Ukrainian migration legislation, which will not be effective without a broad vision and a deep understanding of the migration situation in the country. Today's general understanding of the migration situation and migration flows in Ukraine is not correct and, therefore, some proposals and decisions concerning their management are not adequate. At the level of strategic planning, it would be useful to coordinate the migration policy objectives with the actual demographic and economic situation, social and psychological state of its citizens. Consequently, the economic and legal analysis
\end{abstract}

\footnotetext{
Corresponding author:

${ }^{1}$ Department of Administrative and Information Law, Institute of Law and Psychology, Lviv Polytechnic National University.

E-mail: bnp1969n@gmail.com

${ }^{2}$ Department of Criminal Law and Criminology, National University of the State Fiscal Service of Ukraine.

E-mail: galynadid@gmail.com

${ }^{3}$ Department of Administrative Law and Process and Customs Security, National University of the State Fiscal Service of Ukraine.

E-mail: tilchikvv@ukr.net
} 
of migration moods and migration behaviour of international labour migrants is extremely important for scientific argumentation of the main directions of improvement of the migration policy of Ukraine in the current conditions of globalization for saving labour potential of the state and develop its economy. Methodology. Methodological foundations of the research of international labour migration are determined by a set of methods of scientific knowledge, which allow considering this problem as a multifaceted, interdisciplinary phenomenon. The research strategy, underlying the integrated approach, primarily is based on the following methodological principles: formulation of fundamental theoretical concept; development of cross-cutting concepts and categories, which ensure the unity of the approach to the object of research.

Key words: migration, international labour migration, economic growth, labour market, skilled labour force, demographic potential, legal regulation, migration policy.

JEL Classification: D78, E24, F22

\section{Introduction}

The modern trends of social development are closely linked to the fundamental changes in the socio-political life of the world community. Their characteristic feature is globalization, which has gained an all-encompassing planetary scale at the turn of the millennium. In essence, globalization turned out much wider than its purely economic component having touched all aspects of economic ties and international relations. The modern world reveals an ever-increasing tendency to a more close interaction of individual territories, economies, political, cultural-spiritual, and other fields of activity. The modern information and communication technologies are the basis of such interaction, its direct guides.

The process of globalization is accompanied by an unprecedented increase in trade and capital flows, as well as by the involvement of national economies in a single reproduction process. The deepening of international economic interaction consists of the growth of the interconnection and interdependence of national economies. An effective development of national economic complexes and the entire world economy becomes possible only through the use of the benefits of the global division of labour, the formation of the international labour market, and the free flow of labour power from one country to another (Glushchenko, Ponomarev, 2009).

Thus, one of the forms of cooperation is international labour migration, which has a significant impact on the economy and recipient countries, and donor countries.

At the same time, it is necessary to emphasize that the global labour market is a dynamic entity that reflects the processes taking place in the global economy at each particular stage of its development. The global market serves as a "litmus paper" which shows all weaknesses in the current stage of development of the world economy (Ryazantsev, Tkachenko, 2010).

The transition of the Ukrainian economy to market relations, reforms in the political area and the deepening of the integration processes have created extremely favourable conditions for the full participation of our state in the international labour market. Ukraine's entry into the world market forms new migration flows. Labour migration is more clearly distinguished in the structure of external migration. The involvement of the national labour market in international cooperation, the penetration in the world labour market, the various socio-economic impacts for the participating countries have led to the need for an in-depth analysis of the driving motives of the migration of the labour force and the reasons that hinder this process, its impact on economic development, which is the purpose of this publication. At the same time, scientific comprehension of the problems of international labour migration is necessary for Ukraine to resolve such practical tasks as the development of appropriate national-wide and regional-information and statistical databases for optimal managerial decisions making, first of all, on the maximum use of the potential of labour migrants for the development of the state's economy, limitation of the possibilities for penetration of illegal immigrants into the country territory, elimination of the negative consequences of illegal migration, and most importantly - the development of new regulatory legal acts in the area of migration process assurance with account of the experience of world's powerful countries.

\section{Concept, categories, essential characteristics of international migration}

In the context of our research, it is necessary to underline that the legal aspect of the phenomenon of migration as a whole is the right of a person to freedom of movement and free choice of place of residence. Instead, the formation of national states became the most important event that affected the mobility and distribution of the population on the Earth. The necessity of boundaries establishment was performed to maintain the political, territorial, and administrative integrity, a certain living standard, the ethnic uniqueness of the state and control was implemented in order to limit an excessive number of migrants. According to sovereign right and legitimate interests of states, each of them must have their own migration laws adhering to 
the operative rules of international law and undertaking always to respect the rights and freedoms of a migrant.

It should be noted that in the modern scientific literature on the problem under study, in our opinion, sufficiently comprehensive explanation of the term "external migration" is given, under which it is necessary to understand the Latin expression "migrate, migro", that is, the moving, resettlement. Existing scientific sources explain this term as follows:

- resettlement, moving of people, ethnic groups, their units or separate representatives, connected with the change of permanent residency or return to it (Etnonatsionalnyi rozvytok v Ukraini, 1997);

- moving, resettlement within a country or from one country to another (Ozhegov, 1972);

- the socio-economic and demographic process, which is a set of displacements carried out by people between countries, regions, settlements (Gvishiani, 1989);

- people moving through the territorial boundaries of the state or other territories with the change of residence forever or for a long period of time (Valentey, 1985);

- resettlement, displacement within the country internal migration of people from one country to another - external migration of people: emigration, immigration (Dictionary of foreign words, 1988);

- the movement of people, usually associated with a change of domicile (Azriliyana, 1997);

- the displacement of people, workers, mainly connected with the change of place of domicile and place of work (Riesberg, Lozovsky, Starodubtsev, 1998); - migration of people is a process of their resettlement for the purpose of settlement and employment (Rymarenko, 1998).

The analysis of the above-mentioned points of view shows that the majority of researchers, with minor differences, understand external migration as the movement of people between countries, administrativeterritorial entities, settlements connected mainly with a temporary or permanent change of place of residence, work, and way of life.

Consequently, the main features that allow identifying external migration among other displacements of the population are:

a) displacement of people, resettlement, that is, a process;

b) crossing of state and administrative boundaries of territories in the process of migration movements;

c) temporary or permanent change of place of residence or work.

Instead, in order to gain a better understanding of the impact of international labour migration on the development of states in the context of globalization, it is necessary to pay attention to the content of the basic concepts that characterize the modern migration process.

Potential migration is a psychological readiness of an individual or a group of persons to leave a certain settlement (country). It is characterized by an accepted but still unrealized decision to move. Potential migration is one of the most important characteristics of the migration mobility of individuals.

Migration motivation (migration motives) is a mental state of an individual that prompts him to achieve own goal of economic, social or psychological nature through the change of permanent residence. This concept reveals the qualitative side of the individual's needs to change the place of residence, working conditions, and the implementation of the certain project of life.

Migrant workers are a type of migrants who cross internal and interstate borders in search of work or with the aim to buy or sell a small batch of goods. Typically, migrant workers are unqualified or lowskilled workers who have low social status in a society. However, migrant workers (due to certain reasons or circumstances) become professionals who have a shortage occupation, higher educational attainment and even academic degrees. Migrant workers are divided into three large groups: a) those who left the country of residence forever; b) those who work in another country for a long time; c) so-called labour tourists who cross the interstate borders for a short time (for several days or months). Generally, migrant workers move to the developed countries of Western Europe and North America. The increase of their number, especially in recent years, generates many political and legal, socio-economic, linguistic-cultural and other issues, and often leads to strengthening of anti-migration attitude among a large part of the local population of host countries, which is legally obliged to limit the influx of migrants and to intensify supervision and control over them.

\section{Tendencies and causes of international migration movement in the era of globalization}

Thus, as scientists rightly emphasize, international migration became global at the turn of the millennia reflecting globalization tendencies in various areas of society's activity (Ivanov, 2002). The globalization processes in the labour market, business, education, science, information and communications, as well as social connections, make a particularly significant impact on the movement of the population.

Instead, it should be noted that the following phenomena are new in the globalization process of the late XX - early XXI century:

- the interweaving of national borders in the course of transactions with goods, services or migration labour power;

- the emergence of global environmental awareness of the danger of further prolongation of the arms race, production of technologies and weapons of mass destruction, depletion of the natural environment and exhaustion of natural resources; 
- the emergence of new arenas of intergovernmental regulation to ensure the further life of mankind in time and space;

- transcirculation of technological crops of the reproductive process on the basis of strengthening internationalization of the latter one;

- the growth of the number and power of the so-called new "transnational actors", business entities, various institutions and partnership agreements;

- the growth of economic concentration that resists globalized competition overcoming national boundaries, which is becoming more and more internationally regulated at an international scale.

The above distinctive features of globalization as a process covering all field of human existence, simultaneously denote the sphere of international responsibility for the safety of mankind; compel in a different manner to understand the place and role of the entire arsenal of political, diplomatic, and economic measures of interaction between states and nations in the process of regulation of international relations, which is a part of the international economic relations (Held, McGrew, Goldblatt, Peratton, 1999-2000).

The creation of the international labour market is manifested in the formation of global demand and labour supply, which is reflected, in particular, in the growth of the number of employers, who conduct search and hire of labour power outside national labour markets, an increase of workers group offering their labour to foreign employers (Persian, 2009). The mechanisms that ensure the functioning of this market are developing including the system of national and supranational regulation of issues related to the use of foreign labour, the expansion of activity of foreign employment agencies, which facilitate the extension and regulation of economic labour migration (Massey, 2003). The activities of such agencies fit into the institutional theory of migration, according to which in the course of migration development, there are structures that contribute to it (provide relocation, employment, accommodation, etc.).

Consequently, the main tendencies of modern international migration are: globalization of international migration; qualitative changes in global migration flows; defining role of economic, first of all, labour migration; significant increase in illegal migration; enlargement of the scale and expansion of the geography of forced migration; increasingly large role of international migration in the demographic development of developed countries; feminization of international migration; the double nature of migration policy at the national, international regional and world levels (Iontsev, Kamensky, 2004).

At the same time, in any classification, the main definition is the definition of a migrant as a category. In general, both in science and in the work of practical organizations, including the International Organization for Migration (IOM), the allocation of five main types of international migrants is considered:

- settlers are people who come to the country for permanent residence;

- contract staff are people who have been accepted on the basis of realization that they work for a limited period;

- professionals are people with a high level of education, sufficient work experience, who can easily adjust to a new team and work in a given specialty and at the appropriate level or re-train for work in another country (a significant number of them are scholars, teachers, students and trainees, employees of transnational corporations moving from one branch to another);

- illegal migrants are people who have arrived in the country illegally, have expired visas or engage in labour activity without official permission;

- shelter seekers and refugees are people who have left their countries because of the threat of any significant danger (military, religious, environmental, political, etc.).

At the same time, we can state that among mentioned types of territorial, interstate mobility, labour migration plays a special role. As it migrates, moves between countries the main resource and the factor of production - the ability to work and the labour activity itself.

According to a new study by the International Labour Organization (ILO), migrant workers account for 150.3 million and approximately 232 million international migrants. The ILO Global Estimate on Migrant Workers report shows that migrant workers account for 72.7 per cent of which 206.6 million are working age migrants (15 years old and up). Most of them -83.7 million are men, 66.6 million are women. In his commentary to the report, the ILO DirectorGeneral Guy Ryder said: “These analyses are significant contribution of the ILO to support the Member States to implement Agenda's Sustainable Development Goals on 2030, particularly targets within Goal 8 on protecting all workers, including migrant workers, and Goal 10 on the implementation of well-managed migration policies. Now, those who make decisions will have a real data, a policy can be built on." (http://www.ilo.org....).

\section{Main factors of migration of highly skilled labour power}

A special attention is paid to the migration of highly skilled labour power in the context of the matter under investigation. It should be noted that the growing importance of the international migration of professionals is determined by the following four long-term trends: increasing the life expectancy, reducing birth rates; chronic shortage of labour power in the public sector (especially in healthcare and education); technological changes taking place in the context of national competitiveness increase, 
which create a shortage of highly skilled workers; save of time and money to train the necessary professionals by importing them.

The education system also experiences a significant shortage of skilled personnel. For example, in the UK, the number of non-native teachers has reached 110,000 and takes the third position in the list of specialties occupied by foreign experts (Dobson, Koser, et al., 2001).

At the same time, it should be emphasized that the import of professionals, who are necessary for the economy, leads to the saving of time and money spent on their training (Bartlett, 2006). However, education expenditures are not always taken into account, although these costs are quite significant, especially for such highly educated professionals as engineers. Expenses include the total cost of children' bringing-up, getting of primary, secondary and higher education; payment of scholarships to students studying abroad, continuing education after graduating from higher education institutions and improvement of the professional level; as well as public services that contribute to the creation of a stable environment for this activity. In addition, it should be taken into account that the average productivity of a young professional for the first 2 years is only $60 \%$ (Trevelyan, 2002).

Technological changes are considered one of the most important sources of productivity and economic growth in the new global economy (PricewaterhouseCoopers, Managing mobility issues a European perspective, 2002). Today, the pace of technological changes is so great that society does not have time to absorb it qualitatively. The curve of technological changes is growing at an extremely fast pace.

In the context of the migration problem of highly skilled personnel, it cannot avoid the issue of international student mobility, which is very relevant today for Ukraine. Indeed, at a time when the student migration in its pure form cannot be regarded as a form of migration of skilled scientific and technical personnel, it can precede it. According to the well-known statement of B. Khadria (Khadria, 2004), students are "semi- finished products of human capital." In the last few years, foreign students, including Ukrainian ones, have the opportunity to change their status and obtain a work permit based on their qualifications.

\section{Conclusions}

Summarizing the foregoing, we can state that migration processes, as an integral and permanent component of the history of mankind, have a significant impact on the state and prospects of economic, cultural, and social development of society bringing fresh ideas and enhancing the country's creative potential. Instead, we have a unique opportunity to observe and analyse new, yet insufficiently studied processes that have a certain socio-political orientation and touch the interests of various ethnic groups, the communities of people in general, as well as their specific representatives.

It should be emphasized that in today's knowledgebased economy, considerable attention is being paid to the attraction of labour migrants, especially highly skilled. While it is possible confidently to predict the growing international labour migration, it is difficult to predict with a sufficient degree of probability the quantitative indicators of these flows and certain models of international labour migration.

We believe that the dynamics offlows will be influenced by the situation in the international labour markets of developed countries and developing countries, which will be determined by the ratio of labour's demand and supply; the specialization of global labour markets as new industries and services, emerging in the depths of the new economy, create the need for new knowledge and skills, requiring rapid and effective responses to the labour market that takes into account the development and expansion of modern sectors; the possibilities of its own education system to satisfy it.

The new migration policy should be based on the realities of the global world. For the development of our state, it is necessary to take a full advantage of the current migration situation and opportunities of Ukrainian labour migrants.

\section{References:}

Glushchenko, G.I., Ponomarev, V.A. (2009) Migratsiya i razvitie [Migration and development]. Moscow: ZAO «Izdatelstvo Ekonomika» [in Russian]

Ryazantsev, S.V., Tkachenko, M.F. (2010) Mirovoy rynok truda i mezhdunarodnaya migratsiya [International labour market and international migration]. Moscow: «Izdatelstvo Ekonomika» [in Russian]

(1997) Etnonatsionalnyi rozvytok v Ukraini. Terminy, vyznachennia, personalii [Ethnonational development in Ukraine. Terms, definitions, personalities]. Kyiv. [in Ukrainian]

Ozhegov, S.I. (1972) Slovar russkogo yazyka [Dictionary of the Russian language]. Moscow: Mysl [in Russian]

Gvishiani, D.M. (ed.) (1989) Sovremennyy slovar po sotsiologii [Modern Dictionary of Sociology], Moscow: Nauka [in Russian]

Valentey, D.I. (ed.) (1985) Demograficheskiy entsiklopedicheskiy slovar [Demographic Encyclopedic Dictionary], Moscow: Sov. entsikl. [in Russian]

(1988) Slovar inostrannykh slov [Dictionary of Foreign Words]. Moscow. [in Russian] 
Azriliyana, A.N. (ed.) (1997) Bolshoy ekonomicheskiy slovar [Large Economic Dictionary], Moscow: In-t mirovoy ekonomiki [in Russian]

Rayzberg, B.A., Lozovskiy, L.Sh., Starodubtsev, E.B. (1998) Sovremennyy ekonomicheskiy slovar [Modern Dictionary of Economics]. Moscow.: Infra [in Russian]

Rymarenko, Yu. (ed.) (1998) Mihratsiini protsesy u suchasnomu sviti: svitovyi, rehionalnyi ta natsionalnyi vymiry: Poniatiinyi aparat, kontseptualni pidkhody, teoriia ta praktyka: Entsyklopediia [Migration processes in the modern world: global, regional and national dimensions: conceptual framework, conceptual approaches, theory and practice: Encyclopedia], Kyiv: Dovira [in Ukrainian]

Ivanov, N. P. (2002) Globalizatsiya i problemy sotsialno-ekonomicheskogo razvitiya Rossii [Globalization and problems of Russias socio-economic development]. Moscow: IMEMO RAN. [in Russian]

Held, D., McGrew, A., Goldblatt, D., Peratton, J. (1999-2000) Global Transformation. Oxford-Cambridge: Polity Press, pp. 412-440.

Perskaya, V.V. (2009) Globalizatsiya i gosudarstvo [Globalization and state]. Moscow: RAGS. [in Russian]

Massey, D. (2003) Patterns and Processes of International Migration in the 21st Century, Paper prepared for Conference on African Migration in Comparative Perspective. Johannesburg. Retrieved from http://pum.princeton.edu/pumcomference/papers/1-Massey.pdf

Iontsev, V., Kamenskiy, A. (2004). Mezhdunarodnaya migratsiya naseleniya v Rossii: uroki Kaira [International population migration in Russia: Cairo's lessons]. Mezhdunarodnaya migratsiya: Kair + 10, pp. 10-11.

Dobson, J., Koser, K. (et al.) (2001) International migration and the United Kingdom: Recent patterns and trends. Final Report to the Home Office. L, December. P. 211.

Bartlett, D.L. (2006) Building a Competitive Workforce Immigration and the U.S. Manufacturing Sector. P. 1.

Trevelyan, J.P. (2002) Effects of Skilled Migration: Case Study of Professional Engineers School of Mechanical Engineering. J.P. Trevelyan S. Tilli. Crawley: The University of Western Australia. Dec., p. 26.

Pricewaterhouse Coopers. Managing mobility matters a European perspective. 2002.

Khadria, B. (2004) Migration of Highly Skilled Indians: Case Studies of It and Health Professionals / B. Khadria. Paris: OECD. (STI/WP 2004/6).

Stadnyi, Ye. Kilkist ukrainskykh studentiv za kordonom [Number of Ukrainian students abroad]. Retrieved from: http://www.cedos.org.ua/uk/osvita/56

Malynovska, O. (ed.) (2016) Mihratsiia v Ukraini: fakty i tsyfry [Migration in Ukraine: data and statistics], Predstavnytstvo MOM v Ukraini. [in Ukrainian] 